\title{
PENTINGNYA PROSES DOKUMENTASI PENGKAJIAN KEPERAWATAN DALAM MENENTUKAN DIAGNOSA KEPERAWATAN DENGAN BERFIKIR KRITIS
}

\author{
HOTMAITA HABEAHAN \\ email : hotmaitahabeahan@gmail.com
}

\section{LATAR BELAKANG}

Dokumentasi pengkajian dalam keperawatan memegang peranan penting terhadap segala macam tuntutan masyarakat yang semakin kritis dan mempengaruhi kesadaran masyarakat akan hakhaknya dari suatu unit kesehatan. Dokumentasi pengkajian keperawatan merupakan catatan tentang hasil pengkajian yang dilaksanakan untuk mengumpulkan informasi dari pasien, membuat data dasar tentang pasien, dan membuat catatan tentang respons kesehatan pasien. Pengkajian yang komprehensif atau menyeluruh, sistematis yang logis akan mengarah dan mendukung pada identifikasi masalah-masalah pasien. Masalah-masalah ini dengan menggunakan data penkajian sebagai dasar formulasi yang dinyatakan sebagai diagnosa keperawatan.

Secara umum, dokumentasi pengkajian keperawatan adalah langkah awal dari melakukan proses keperawatan atau pemberian asuhan keperawatan. Pengkajian keperawatan bertujuan untuk mengetahui masalah yang dihadapi oleh klien dengan cara mengumpulkan data klien, sehingga perawat dapat memberikan asuhan atau tindakan keperawatan dengan benar. Dalam melakukan pengkajian, harus memerlukan keahlian, seperti wawancara, pemeriksaan fisik, dan observasi serta memerlukan ketelitian dan kecermatan agar dalam melakukan proses keperawatan pada tahap pengkajian dapat berhasil. Oleh sebab itu, untuk mengetahui cara berhasilnya dalam melakukan asuhan keperawatan, diperlukan langkah-langkah untuk melakukan pengkajian, seperti pengumpulan data, klasifikasi data, validasi data, dan perumusan masalah.

Diagnosa keperawatan adalah keputusan klinis mengenai seseorang, keluarga, atau masyarakat sebagai akibat dari masalah kesehatan atau proses kehidupan yang aktual atau potensial. 
Diagnosa keperawatan merupakan dasar dalam penyusunan rencana tindakan asuhan keperawatan.

\section{METODE}

Proses dokumentasi pengkajian keperawatan dalam menentukan diagnose menggunakan metode pengumpulan data dari sumber yang sudah terjamin datanya seperti melalui Jurnal dan Textbook dari tahun 2012 hingga 2020. Pengambilan informasi melalui Jurnal dan Textbook adalah untuk mendapatkan berbagai informasi yang lengkap dan akurat dengan cara penyimpulan. Penyimpualan yang dilakukan adlah dengan menggunakan bahasa sendiri tanpa ada meniru karya orang lain.

Selain itu berdasarkan Jurnal yang sudah didapat menggunakan metode penelitian deskriptif ekploratif dengan menggunakan pendekatan kuantitatif, desain penelitian ini adalah penelitian deskritif yaitu penelitian yang bertujuan untuk mendeskripsikan peristiwa penting yang terjadi pada masa kini, penelitian ini merupakan penelitian kuantitatif dengan desain penelitian potong lintang dan bersifat deskriptif korelatif dan metode jenis penelitian kuantitatif deskriptif dengan pendekatan observasional.

\section{HASIL}

Berdasarkan sumber data Jurnal dan Textbook yang sudah saya temukan, bahwasanya dalam proses dokumentasi dan pengkajian merupakan peranan penting dan langkah awal dalam melakukan proses keperawatan. Begitu juga di dalam diagnosa keperawatan dokumentasi dan pengkajian sangat begitu penting. Mengapa hal ini penting, karena diagnose pengkajian keperawatan adalah proses mengumpulkan informasi dari pasien, membuat data dasar tentang pasien, dan membuat catatan tentang respons kesehatan pasien.

Dijurnal juga dikatakan bahwa sebagian perawat merasakan bahwa melaksanakan pendokumentasian bukan merupakan kewajiban profesi, melainkan sebagai suatu beban. Bahkan, banyak perawat yang masih belum sepenuhnya memahami penulisan dokumentasi pengkajian. Namun dokumentasi pengkajian keperawatan ini sangat penting karena dari pengkajian keperawatan maka perawat akan mampu menentukan apa masalah keperawatan/diganosa keperawatan dan masalah kolaboratif/diagnosis potensial komplikasi yang dialami oleh pasien 
dan membuat perencanaan dalam merawat pasien. Tapi terbukti dari penelitian jurnal masih banyak perawat yang lalai akan hal ini

Berdasarkan Jurnal menunjukkan bahwa sering sekali perawat kesulitan dalam menentukan diagnosis keperawatan spesifik yang dialami oleh pasien. Hal ini mungkin dikarenakan pengkajian keperawatan yang tidak terstruktur dengan baik. Oleh karena itu, ketika melakukan penelitian mengenai diagnosis keperawatan harus berfokus pada keakuratan data dokumentasi pengkajian. Sering terjadi perawat mempunyai data tertentu tetapi kebingungan untuk menentukan data tersebut mendukung diagnosis keperawatan yang mana. Atau sebaliknya perawat mempunyai prediksi pasien mempunyai diagnosis tertentu tetapi tidak tahu data apa yang perlu dikaji untuk mendukung diagnosis tersebut muncul.

Data menunujukkan bahwa diagnosis keperawatan yang ditegakkan berdasarkan pengkajian NANDA-ISDA lebih beragam daripada diagnosis keperawatan yang ditegakkan oleh perawat. Dengan NANDA-ISDA pengkajian dilakukan dari berbagai Aspek dan didasari pada pemahaman terhadap definisi suatu diagnosis tersebut. Sedangkan diagnosis yang dibuat perawat tidak didasari pada pengkajian dan pemahaman tentang definisi diagnosis itu sendiri.

\section{PEMBAHASAN}

Dokumentasi pengkajian keperawatan merupakan catatan tentang hasil pengkajian yang dilaksanakan untuk mengumpulkan informasi dari pasien, membuat data dasar tentang pasien, dan membuat catatan tentang respons kesehatan pasien. Pengkajian yang komprehensif atau menyeluruh, sistematis yang logis akan mengarah dan mendukung pada identifikasi masalahmasalah pasien. Masalah-masalah ini dengan menggunakan data penkajian sebagai dasar formulasi yang dinyatakan sebagai diagnosa keperawatan.

Diagnosa keperawatan ditegakkan berdasarkan respon fisik, sosio-kultural, psikologis, dan spiritual klien terhadap masalah kesehatannya yang bersifat individual, sehingga diperlukan kemampuan berpikir kritis dalam proses diagnostik. Penegakkan diagnosa keperawatan haruslah didukung sekelompok data dasar yang didapatkan oleh perawat saat melakukan pengkajian. Kelompok data ini disebut batasan karakteristik. Batasan karakteristik adalah indikator klinis yang merupakan tanda dan gejala objektif atau subjektif atau factor risiko yang mendukung adanya kategori diagnostik.

Metode dokumentasi dalam pengkajian keperawatan bertujuan untuk : 
1. Mengumpulkan, mengorganisir, dan mencatat data yang menjelaskan respon manusia yang mempengaruhi pola-pola kesehatan pasien.

2. Hasil dokumentsi pengkajian akan menjadi dasar penulisan rencana asuhan keperawatan

3. Memberikan keyakinan tentang informasi dasar tentang kesehatan pasien untuk dijadikan referensi status kesehatannya saat ini atau yang lalu

4. Memberikan data yang cukup untuk menentukan strategi perawatan yang sesuai dengan kebutuhan pasien.

Dalam melaksanakan dokumentasi pada tahap pengkajian perlu diketahui bahwa jenis dokumentasi keperawatan meliputi:

1. Dokumentasi pada saat pengkajian awal (InitialAssessment)

Dokumentasi yang dibuat ketika pasien pertama kali masuk rumah sakit. Data yang dikaji pada pasien berupa data awal yang digunakan sebagai dasar dalam pemberian asuhan keperawatan.

2. Dokumentasi pengkajian lanjutan (Ongoing Assessment)

Data pada dokumentasi ini merupaka pengembangan dasar yang dilakukan untuk melengkapi pengkajian awal dengan tujuan semua data menjadi lengkap sehingga mendukung infromasi tentang permasalahan kesehatan pasien. Hasil pengkajian ini dimasukkan dalam catatan perkembangan terintegrasi pasien atau pada lembar data penunjang.

3. Dokumentasi pengkajian ulang (Reassessment)

Dokumentasi ini merupakan pencatatan terhadap hasil pengkajian yang didapat dari informasi selama evluasi. Perawat mengevauasi kemajuan dta terhadap pasien yang sudah ditentukan.

Diagnosa keperawatan adalah keputusan klinis mengenai seseorang, keluarga, atau masyarakat sebagai akibat dari masalah kesehatan atau proses kehidupan yang aktual atau potensial. Diagnosa keperawatan merupakan dasar dalam penyusunan rencana tindakan asuhan keperawatan.Diagnosis keperawatan sejalan dengan diagnosis medis sebab dalam mengumpulkan data-data saat melakukan pengkajian keperawatan yang dibutuhkan untuk menegakkan diagnosa keperawatan ditinjau dari keadaan penyakit dalam diagnosa medis. 
Dalam merumuskan diagnosis keperawatan terdapat beberapa kegiatan yang dilakukan dalam mendiagnosis keperawatan adalah interpretasi dari data yang ada, kemudian melakukan verifikasi dengan pasien, menentukan label diagnosis keperawatan dan menuliskan diagnosis keperawatan.

Tujuan dokumentasi diagnosa keperawatan adalah:

1. Menyampaikan masalah klien dalam istilah yang dapat dimengerti semua perawat

2. Mengenali masalah-masalah utama klien pada pengkajian

3. Mengetahui perkembangan keperawatan

4. Masalah dimana adanya respons klien terhadap status kesehatan atau penyakit

5. Faktor-faktor yang menunjang atau menyebabkan suatu masalah (etiologi)

6. Kemampuan klien untuk mencegah atau menyelesaikan masalah

Diagnosa keperawatan dapat dibedakan menjadi 5 kategori :

1. Aktual

Diagnosa Keperawatan aktual menjelaskan masalah nyata saat ini sesuai dengan data klinik yang ditemukan. Syarat menegakkan diagnosa keperawatan aktual harus ada unsur PES.Symptom (S) harus memenuhi kriteria mayor dan sebagian kriteria minor dari pedoman diagnosa NANDA.

2. Risiko

Diagnosa Keperawatan Risiko menjelaskan masalah kesehatan yang nyata akan terjadi jika tidak dilakukan intervensi. Syarat menegakkan risiko diagnosa keperawatan adanya unsur PE (problem dan etiologi).Penggunaan istilah "risiko dan risiko tinggi" tergantung dari tingkat keparahan/kerentanan terhadap masalah. Diagnosa: "Risiko gangguan integritas kulit berhubungan dengan diare yang terus menerus".

3. Kemungkinan

Diagnosa Keperawatan Kemungkinan menjelaskan bahwa perlu adanya data tambahan untuk memastikan masalah keperawatan kemungkinan.Pada keadaan ini masalah dan faktor pendukung belum ada tapi sudah ada faktor yang dapat menimbulkan masalah.Syarat menegakkan kemungkinan diagnosa keperawatan adanya unsur respons dan faktor yang mungkin dapat menimbulkan masalah tetapi belum ada.

4. Diagnosa Keperawatan "Wellness" 
Diagnosa keperawatan wellness (sejahtera) adalah keputusan klinik tentang keadaan individu, keluarga, dan atau masyarakat dalam transisi dari tingkat sejahtera tertentu ke tingkat sejahtera yang lebih tinggi. Ada 2 kunci yang harus ada:

a. Sesuatu yang menyenangkan pada tingkat kesejahteraan yang lebih tinggi

b. Adanya status dan fungsi yang efektif.

Analisis pertanyaan kritis pada Tahap Penentuan diagnosa antara lain:

1. Analisis data.

Untuk melakukan analisis data, data yang ada dari hasil pengkajian sehingga mampu mengidentifikasi data subyektif dan obyektif yang mendukung masalah keperawatan, data normal sudah diketahui sehingga mampu menganalisis data yang merupakan data fokus yang mendukung masalah keperawatan, selanjutnya melakukan pengelompokan data yang ada dalam kelompok subyektif dan obyektif

2. Identifikasi masalah klien

Dalam mengidentifikasi masalah hendaknya terdapat data subyektif dan obyektif sehingga mampu memutuskan masalah yang ada merupakan masalah aktual,resiko atau kemungkinan. Pada tahap identifikasi masalah mendokumentasikan hanya sebatas masalah keperawatan bukan diagnosis keperawatan dan Masalah keperawatan harus di identifikasi sesuai data subyektif dan obyektif yang ada.

3. Membuat pernyataan diagnosis keperawatan

Pada tahap analisis data kegiatan yang dilakukan adalah menganalisis masalah keperawatan yang telah didokumentasikan, menentukan etiologi / penyebab dari masalah keperawatan yang ada dengan menganalisis kembali data subyektif dan obyektif yang sudah dikelompokkan sesuai dengan masalah, menentukan diagnosis keperawatan terdiri dari problem,etiologi dan tanda / data subyektif dan obyektif.

4. Memprioritaskan diagnosis keperawatan

Dalam melakukan prioritas diagnosis keperawatan dengan cara menganalisis diagnosa keperawatan yang ada pada pasien kemudian membuat prioritas diagnose berdasarkan hirarki Maslow dengan urutan : keadaan yang mengancam kehidupan, kesehatan dan persepsi tentang kesehatan dan keperawatan.

5. Mendokumentasikan diagnosis keperawatan 
Untuk melakukan dokumentasi diagnosis keperawatan hendaknya sesuai prioritas, tanggal ditemukannya diagnosa keperawatan. Melakukan pencatatan sebagai pertanggung jawaban yang harus disertai nama jelas dan paraf serta dokumentasi ditulis dengan tepat, lengkap dan mudah dibaca serta dimengerti oleh Tim Kesehatan lain yang terkait.

\section{PENUTUP}

Dokumentasi pengkajian keperawatan merupakan catatan tentang hasil pengkajian yang dilaksanakan untuk mengumpulkan informasi dari pasien, membuat data dasar tentang pasien, dan membuat catatan tentang respons kesehatan pasien. Pengkajian yang komprehensif atau menyeluruh, sistematis yang logis akan mengarah dan mendukung pada identifikasi masalahmasalah pasien.

Diagnosa keperawatan ditegakkan berdasarkan respon fisik, sosio-kultural, psikologis, dan spiritual klien terhadap masalah kesehatannya yang bersifat individual, sehingga diperlukan kemampuan berpikir kritis dalam proses diagnosis.

Dalam merumuskan diagnosis keperawatan terdapat beberapa kegiatan yang dilakukan dalam mendiagnosis keperawatan adalah interpretasi dari data yang ada, kemudian melakukan verifikasi dengan pasien, menentukan label diagnosis keperawatan dan menuliskan diagnosis keperawatan.

\section{DAFTAR PUSTAKA}

Apriyani, Heni., Identifikasi Diagnosis Keperawatan pada Pasien di Ruang Paru Rumah Sakit Jurnal Keperawatan, Volume XI, No. 1, April 2015 ISSN 1907 - 0357

Damhudi, Dedi., Irawaty, Dewi., Hariyati, S. T. Rr. Efektifitas Metode NIHSS dan ESS dalam Membuat Diagnosa Keperawatan Aktual pada Pasien Stroke Berat Fase Akut Volume 15 No. 1, Maret 2012; hal 712

Dinarti., Mulyanti, Yuli., Buku Bahan Ajar Keperawatan Dokumentasi Keperawatan, edisi Oktober 2017 
Efendy M. A ., Purwandari Retno., Perbedaan Tingkat Kualitas Dokumentasi Proses Keperawatan Sebelum dan Sesudah Penerapan Nansa-I, NIC dan NOC. Jurnal Keperawatan Soedirman (The Soedirman Journal of Nursing), Volume 7, No.2, Juli 2012

Indriatie.,Berfikir dalam Proses Keperawatan (critical thinking in the nursing process) VOL. VI NO. 2 Agustus 2013 ISSN 1979-8091

Koerniawan Dheni., Daeli N. E., Srimiyati., Aplikasi Standar Proses Keperawatan : Diagnosis, Outcome, dan Intervensi pada Asuhan Keperawatan., Jurnal Keperawatan Silampari Volume 3, Nomor 2, Juni 2020 e-ISSN: 2581-1975 p-ISSN: 2597-7482

Lestari, T. R. Pendidikan Keperawatan : Upaya Menghasilkan Tenaga Perawat Berkualitas (Nursing Education: Effort to Produce Quality Nurses Personnel) Vol. 5 No. 1, Juni 2014

Pramithasari, I. D. Gambaran Kinerja Perawat dalam Mendokumentasikan Asuhan Keperawatan Berbasis Komputer di RSUD Banyumas Jurnal Keperawatan Muhammadiyah 1(1) 2016

Salim, Agus., Faktor - factor yang Berhubungan dengan Kelengkapan Dokumentasi Pengkajian Rawat Jalan di Rumah Sakit Awal Bros Batam 2016(Factors That Related To The Documentation Completeness Of Outpatient Assestment in Hospital Awal Bros Batam Year 2016) Journal of Hospital Administration and Management Vol 1, No. 1, Juni 2020

Sari, S. H., Agianto., Wahid, Abdurahman. Batasan Karakteristik dan Faktor yang Berhubungan (Etilogi) Diagnosa Keperawatan : Hambatan Fisik pada Pasien Stroke DK Vol.3 No.1 Maret 2015

Simamora, R. H. (2019). Socialization of Information Technology Utilization and Knowledge of Information System Effectiveness at Hospital Nurses in Medan, North Sumatra. Editorial Preface From the Desk of Managing Editor..., 10(9). 
Supratti., Ashriady., Pengkajian Standar Asuhan Keperawatan di Rumah Sakit Umum Daerah Mamuju, Indonesia Volume 2, Nomor 1, Juli 2016 ISSN: 2443-3861

Yanti, R. I. Warsito, B. E. (2013) Hubungan Karakteristik Perawat, Motivasi dan Supervisi dengan Kualitas Dokumentasi Proses Asuhan Keperawatan. Volume 1, No. 2, November 2013; $107-114$ 